苐一圖版

PL. I.

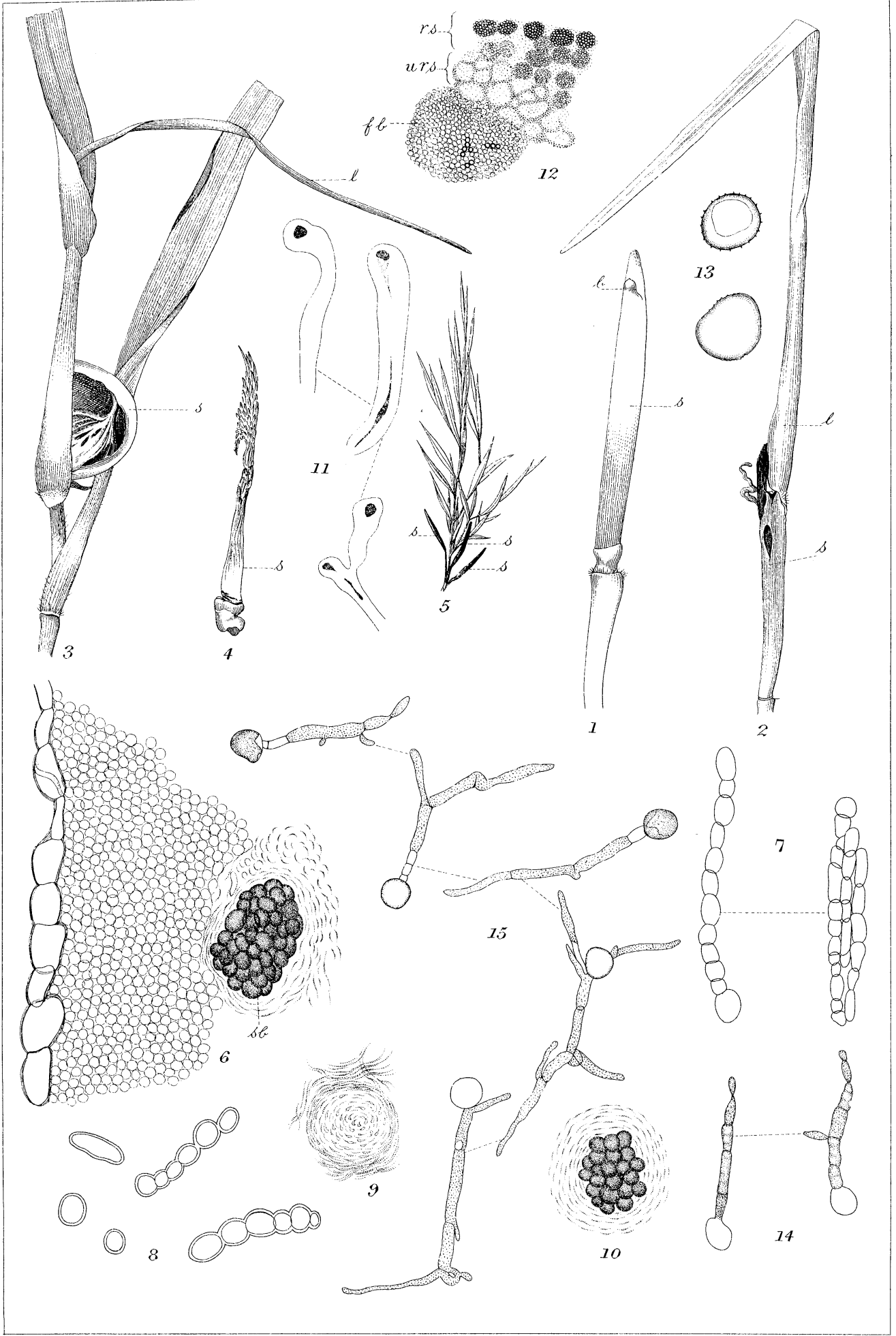

Takahashi del. Sorosporium Panici miliacei (Pers)Takahashı. 


\title{
On Ustilago Panici miliacei (Pers.) Winter.
}

\author{
By
}

Y. Takahashi, Nögakushi.

With Plate I.

RÉSUMÉ.

1. Ustilago Panici miliacei occurs very abundantly on Panicum miliaceum in Hokkaidō (Yezo).

2. Usually the whole inflorescence is changed into the smutpustule bearing sometimes an undeveloped bract on or near its apex (Fig. I).

3. The internode immediately below the inflorescence is often affected and forms the lower portion of the smutpustule; in this case a more or less well developed leaf is borne on the smutpustule (Figs. II and III). Partially smutted inflorescences are also very rarely found (Fig. IV and $\mathrm{V}$ ).

4. The coating of the smutpustule consists of the epidermis of the host and a layer of sterile hyphe, which is in close contact with the inner surface of the epidermis (Fig. VI).

5. The smutpustule is traversed lodgitudinally by the vascular bundles of the host and the strands of sterile hyphe, spoken of by Dietel ${ }^{(1)}$ as Zellcomplexe in the case of Ustilago Ischæmi Fckl.

6. The hyphe of these strands, which are similar to, but distinctly bigger than, those of the coating, are close-septate and become divided up into round or oblong simple cells, when the spores are ripe (Fig. VIII).

7. The spores are produced at the end of strongly gelatinized hyphal branches which compactly intertwine forming a large ball. (Fig. IX and $\mathrm{XI})$.

(1) P. Dictel:-Untersuch. über einige Brandpilze. Flora, 1897. 
8. The spore-balls are surrounded while they are young by an investment consisting of gelatinous sterile hyphe (Figs. VI, sb and X). At maturity, these balls which then measure $45-105 \mu \times 45-85 \mu$ in size lose their investment and become easily separable.

9. The spore-balls are formed in more or less concentric rings around each vascular bundle, and the ripening proceeds centripetally toward the bundle (Fig. XII).

10. As can be gathered up from the above account, the present species is evidently referable to the genus Sorosporium, and should bear the name Sorosporium Panici miliacei (Pers.).

11. Resemblance of the fungus in question to Sorosporium Syntherisma (Schwn.) Farlow was pointed out by Pammel(1) in 1892, when the latter species was still being retained in the genus Ustilago.

12. The hyphal stratum inside the epidermis of the smutpustule is well developed in Sorosporium Syntherisme and also in S. Everhortii Ell. et Gall., as far as my observation is concerned. This is also the case with S. Ehrenbergii Kühn according to Dietel. ${ }^{(2)}$ In the abovenamed two species of Sorosporium, however, the hyphal strands are wanting in the smutpustule, at least, in the specimens which I have examined.

Agricultural Experiment Station,

Sapporo, Hokkaido, Japan, Sep't. 25, 1902

Explanation of Figures in Plate $I$.

(In Figs. I-V. s represents smutpustule; l, leaf.)

Fig. I.-Whole inflorescence above the uppermost node transformed into smutpustule bearing a bract, br., natural size.

Fig. II.--Inflorescence and the internode immediately below it transformed into smutpustule; one-half natural size.

Fig. III.- Fully ripened smutpustule; the leaf, l, borne on the latter is nearly dried up; one-half natural size.

(1) L. H. Pammel, New Fungus Diseases of Iowa. Journ. of Mycology, 1892.

(2) P. Dietel :-Hemibasidii (in Engler-Prantl's Pflanzenfamilien.) 
Fig. $I V$. and Fig. V.-Partially smutted inflorescences, natural size.

Fig. VI.-Cross section of the coating of smutpustule; a spore-ball with its investment is also shown $; \times 390$.

Fig. VII.-Hypha of the coating, $\times 390$.

Fig. VIII.-Hyphre of the mycelial strands in the smutpustule, and three simple cells produced by the breaking up of the hyphæ; $\times 390$.

Fig. IX.-Very young spore-ball, $\times 390$.

Fig. $\quad X$.-Spore-ball in a later stage, $\times 390$.

Fig. XI.-Fertile hyphal branches of which spore-balls are composed; $\times 940$.

Fig. XII. - A portion of cross section showing the arrangement of sporeballs; $r s$, ripe spore-balls; urs, unripe spore-balls; $f \mathrm{~b}$, vascular bundle; $\times 91$.

Fig. XIII.-Spores, $\times 940$.

Fig. XIV.-Germination of spores in water, $\times 390$.

Fig. XV.-Germination of spores in nutrient solution, $\times 390$.

\section{Enumeration of Corallinaceous Algæ hitherto known from Japan.}

By

K. Yendo, Rigakushi.

FAM. CORALLINACEAE.

Subfam. MELOBESIE, Aresch.

\section{CHOREONEMA, Schm.}

Ch. Thureti, Schm. System. Uebersicht d. bish. bekan. Gat. d. Flor. (Flora 1889)=Melobesia Thureti, Born: Born. et 'Thur; Etud. Phyc. p. 96. Pl. 50-Hauck: Meeresalg. p. 261. fig. 105.

Habit. On Corallina decussato-dichotoma; Misaki, Prov. Sagami! 